\title{
PEMODELAN PENYEBARAN INFEKSI COVID-19 DI KALIMANTAN, 2020
}

\author{
Rony Teguh $^{\mathrm{a}, 1, *}$, Abertun Sagit Sahay ${ }^{\mathrm{b}, 2}$, Fengky F Adji ${ }^{\mathrm{c}, 3}$ \\ ${ }^{a}$ Fakultas Teknik, Jurusan Teknik Informatika, Universitas Palangka Raya \\ ${ }^{\mathrm{b}}$ Program Pascasarjana, Program Studi Pengelolaan Sumber Daya Alam dan Lingkungan, Universitas Palangka Raya \\ ${ }^{1}$ ronnyteguh@gmail.com*; ${ }^{2}$ fengky77@gmail.com; \\ * corresponding author
}

ARTICLE INFO

Keywords

COVID-19

SIR Model

Epidemi

Kalimantan

prediksi

\section{ABSTRACT}

In the regional scale of the province in Kalimantan, the spread case appeared in West Kalimantan and East Kalimantan on 18th March 2020, Central Kalimantan on 20th March 2020, South Kalimantan on 22nd March 2020 and North Kalimantan on 29th March 2020. In this case the Covid-19 epidemic was caused by coronavirus disease 2019 (Covid-19). The prediction of the Covid-19 is currently sought. We use the SIR Model to perform basic reproductive value calculations (R0). This model is the mathematic language, interpreted as the number of nativity of a new case due to a person infected with Covid19 into a fully healthy and potential population for illness or infection by the Covid-19. Using the linear regression, we estimate the value of $\mathrm{R} 0$. The value of R0 in Kalimantan region is West Kalimantan (R0 = $1.15)$, East Kalimantan $(\mathrm{R} 0=1.17)$, Central Kalimantan $(\mathrm{R} 0=1.09)$, South Kalimantan $(\mathrm{R} 0=1.24)$, and North Kalimantan $(\mathrm{R} 0=1.20)$. According to the SIR Model, the highest R0 value is in South Kalimantan, followed by North Kalimantan, East Kalimantan, West Kalimantan, and Central Kalimantan.

\section{Pendahuluan}

Kasus pertama penyebaran penyakit pernafasan terjadi pada bulan Desember 2019 yang teridentifikasi di daerah Wuhan, Provinsi Hubei, China. Pada 11 Februari 2020, Wabah virus ini menjadi perhatian lembaga Internasional World Health Organization (WHO) yang menginformasikan adanya virus baru dengan nama coronavirus 2019 (COVID-19). Sumber penularan coronavirus baru belum dapat ditentukan sejauh ini. Dari berbagai bukti menunjukkan bahwa sumber infeksi virus corona baru berasal dari hewan liar[1]. Virus Corona baru menyebabkan penularan dari manusia ke manusia terutama oleh bersin, demam, batuk, dan gangguan pernapasan. Kejadian di Indonesia, pertama kali kasus Covid-19 ini diumumkan oleh Gugus Tugas COVID-19 Indonesia pada tanggal 2 Maret 2020. Untuk skala regional dalam hal ini provinsi yang ada di Kalimantan, kasus penyebaran muncul di Kalimantan Barat (Kalbar) dan Kalimantan Timur (Kaltim) pada tangal 18 Maret 2020, Kalimantan Tengah (Kalteng) pada tanggal 20 Maret 2020, Kalimantan Selatan (Kalsel) pada tanggal 22 Maret 2020, dan Kalimantan Utara (Kaltara) pada tanggal 29 Maret 2020. Pada Tabel 1 dapat dilihat, jumlah kasus COVID-19 yang dilaporkan secara mingguan mengalami peningkatan dari hari ke hari.

Tabel 1. Jumlah Laporan Kasus COVID-19 di Kalimantan (sumber: www.covid19.go.id)

\begin{tabular}{|c|c|c|c|c|c|}
\hline \multirow{2}{*}{ Minggu } & \multicolumn{5}{|c|}{ Jumlah Kasus } \\
\cline { 2 - 6 } & Kalbar & Kaltim & Kalteng & Kalsel & Kaltara \\
\hline $18 / 03 / 2020-22 / 03 / 2020$ & 0 & 10 & 2 & 1 & 0 \\
\hline $23 / 03 / 2020-29 / 03 / 2020$ & 1 & 8 & 4 & 1 & 2 \\
\hline $30 / 03 / 2020-5 / 04 / 2020$ & 2 & 13 & 5 & 14 & 6 \\
\hline $6 / 04 / 2020-12 / 04 / 2020$ & 5 & 5 & 13 & 18 & 8 \\
\hline $13 / 04 / 2020-19 / 04 / 2020$ & 8 & 24 & 22 & 62 & 53 \\
\hline
\end{tabular}




\begin{tabular}{|c|c|c|c|c|c|}
\hline \multirow{2}{*}{ Minggu } & \multicolumn{5}{|c|}{ Jumlah Kasus } \\
\cline { 2 - 6 } & Kalbar & Kaltim & Kalteng & Kalsel & Kaltara \\
\hline $20 / 04 / 2020-26 / 04 / 2020$ & 30 & 38 & 54 & 50 & 14 \\
\hline $27 / 04 / 2020-3 / 05 / 2020$ & 17 & 49 & 53 & 33 & 33 \\
\hline $4 / 05 / 2020-10 / 05 / 2020$ & 48 & 52 & 32 & 58 & 9 \\
\hline
\end{tabular}

Seperti yang di tampilkan pada Tabel 1, jumlah kasus per provinsi di Kalimantan secara mingguan selalu bertambah. Tujuan dari studi ini adalah melakukan pemodelan terhadap penyebaran epidemik virus Covid-19 di Kalimantan, dimana hasil prediksi yang dihasilkan dapat membantu untuk bertindak secara tepat dan meminimalkan dampak dari resiko epidemik wabah COVID-19. Berdasarkan data epidemik untuk regional Kalimantan yang ditampilkan pada Tabel 1 di atas memiliki ketidakpastian pada sebaran data orang yang terjangkit, yaitu 1). Bahwa orang yang terinfeksi tanpa gejala dapat menyebarkan penularan virus Covid-19 dan 2). Karena tidak ada/terbatasnya fasilitas untuk melakukan tes diagnostik sederhana yang berguna sebagai pelacakan penyebaran virus. Pada studi ini, dengan mempertimbangkan ketidakpastian tersebut, kami menerapkan sebuah model matematika untuk pandemik yang dipergunakan sebagai alat prediksi terjadinya pandemik di Kalimantan.

\section{Metodologi}

\subsection{Data}

Data untuk analisis perhitungan prediksi Covid-19 ini diperoleh dari database yang tersedia untuk umum dan website. Data yang diambil di website www.covid19.go.id berupa data harian untuk wilayah Kalimantan. Adapun data diambil dari tanggal 18/03/2020 sampai dengan tanggal 10/05/2020. Dalam studi ini, data yang di gunakan adalah data yang terkonfirmasi positif, sembuh, dan meninggal. Pengambilan data pada tanggal saat dilaporkan terkonfirmasi positif oleh pemerintah. Pada studi ini mengunakan masa inkubasi selama 7 hari, dengan dugaan awal terjangkit di per daerah. Untuk provinsi Kalbar dan Kaltim terlaporkan pada tanggal 11 maret 2020. Sedangkan provinsi Kalteng pada tanggal 13 Maret 2020. Untuk provinsi Kalsel pada tanggal 15 Maret 2020 dan Kaltara pada tanggal 22 maret 2020.

\subsection{Model}

Dalam studi ini, kami menerapkan sebuah model matematika epidemik yaitu model SIR kompartemen untuk prediksi penyebaran epidemik pada kawasan regional Kalimantan. Model SIR ini diperkenalkan oleh Kermack dan McKendrick yang dipublikasikan pada tahun 1927. Model ini terbagi menjadi 3 (tiga) variabel yaitu S (Susceptible), yaitu jumlah orang yang mempunyai potensi untuk terpapar sebuah penyakit. I (Infected), yaitu jumlah orang yang sudah terinfeksi, dan $\mathrm{R}$ (Recovered), yaitu jumlah orang yang sudah resisten, kebal, mempunyai imun terhadap penyakit tersebut. Untuk model dinamik penyebaran virus kami mengunakan persamaan diferensial, dimana parameter $\beta$ sebagai kontrol dari perpindahan antara S dan I. Sedangkan $\gamma$ adalaha parameter kontrol dari I ke R. Model dapat di gambarkan sebagai berikut.

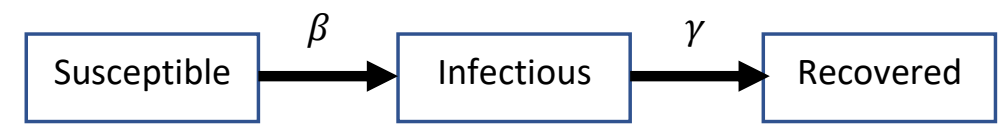

Dan untuk persamaan diferensial berpasangan adalah 


$$
\begin{aligned}
& \frac{d S}{d t}=-\beta S I, \\
& \frac{d I}{d t}=\alpha E-\gamma I \\
& \frac{d R}{d t}=\gamma I
\end{aligned}
$$

Dimana dS, dI, dan dR menunjukan Susceptible, Infective, dan Recovered dari populasi waktu dt. Dari masing masing parameter $\beta$ dan $\gamma$ menunjukan masa terinfeksi dan sembuh. Dengan nilai kontanta populasi $\mathrm{S}+\mathrm{I}+\mathrm{R}=\mathrm{N}$. Kami juga mengestimasi untuk nilai $R_{O}$ sebagai nilai reproduksi rasio awal untuk model ini.

$$
R_{o}=\frac{\beta}{\gamma}>1
$$

Pada studi ini, pemodelan mengunakan beberapa koefisien. Untuk yang pertama adalah variabel $\beta$, yaitu transmission rate adalah menunjukkan seberapa cepat virus menular ke individu-individu. Untuk menentukan variabel $\beta$ dan $\gamma$, di estimasi dengan jumlah penduduk (lihat tabel 2) dan waktu terinfeksi.

Penelitian mengenai COVID-19 dengan mengunakan model matematika telah dilakukan untuk prediksi dan estimasi untuk sebaran virus. Sahafizadeh et al[2] mengunakan permodelan SIR untuk mengestimasi angka reproduksi COVID19 di Iran. Liang [3], melakukan pemodelan mengunakan tentang dinamik model untuk penyebaran infeksi pada karateristik COVID-19, SARS dan MARS. Singh et al[4]. Mereka melakukan simulasi pemodelan di India untuk COVID-19 dengan mengunakan model eksponensial. Chen et al [5]. mereka melakukan studi mengunakan SIR model untuk orang yang tidak terdeteksi oleh infeksi virus. Waqas et al[6]. Studi yang dilakukan di Pakistan menggunakan time dependent SIR model untuk memprediksi puncak pandemik.

Tabel 2. Jumlah Populasi Penduduk di Kalimantan (sumber www.bps.go.id)

\begin{tabular}{|c|c|c|c|c|}
\hline \multicolumn{5}{|c|}{ Jumlah Populasi (jiwa) } \\
\hline Kalbar & Kaltim & Kalteng & Kalsel & Kaltara \\
\hline 5.069 .127 & 3.721 .389 & 2.769 .156 & 4.303 .979 & 695.562 \\
\hline
\end{tabular}

Untuk melakukan pencocokan (matching) kurva dari model ke data, dalam studi ini melakukan persamaan numerik diferensial dan optimasi. Pada persamaan diferensial, fungsi yang digunakan adalah model dari deSolve paket. Kami juga melakukan optimasi pada model dengan mengunakan fungsi optimum dari aplikasi R project (www.r-project.org). Kami juga melakukan perhitungan fungsi minimal dari jumlah yang $\mathrm{I}(\mathrm{t})$ terhadap waktu $(\mathrm{t})$ dan berhubungan dengan nilai prediksi dari model $\dot{\mathrm{I}}(\mathrm{t})$.

$$
R S S(\beta, \gamma)=\sum_{t}\left(I(t)-(\dot{\mathrm{I}}(t))^{2}\right.
$$

Untuk melakukan perhitungan herd immunity pada kawasan Kalimantan dengan menggunakan persamaan sebagai berikut

$$
V_{c}=\left(1-\frac{1}{R_{0}}\right)
$$

Dimana Vc adalah minimum proposi yang akan divaksinasi atau memiliki kekebalan sendiri. 

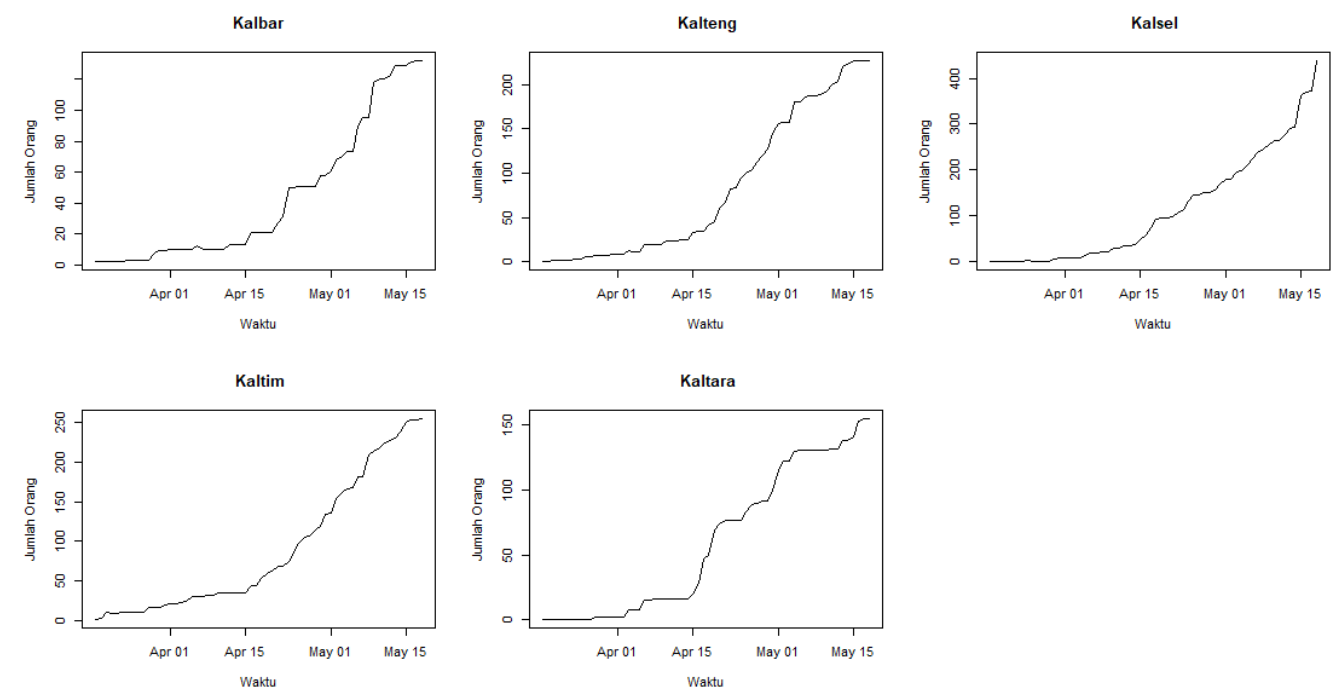

Gambar 1. Data Pasien Positif di Kalimantan

\section{Hasil dan Pembahasan}

2.1 Model SIR untuk penyebaran Covid-19

Dalam studi ini, kami melakukan simulasi dan estimasi data pada wilayah Kalimantan dengan mengunakan epidemik SIR model. Dari data Tabel 1 yang merupakan jumlah data terinfeksi dari hari ke hari yang di komulatifkan dalam satuan minggu. Pada studi ini kami mengunakan metode pemrograman Statistik R Project dengan referensi paket pendukung deSolve untuk melakukan perhitungan persamaan diferential. Gambar 1 menunjukkan gambaran awal jumlah kasus Covid-19 di Kalimantan. Dalam hal ini, untuk wilayah Kalimantan yaitu Kalsel dan Kaltim memiliki tingkat kasus positif corona virus tertinggi di banding daerah lain yang ada di Kalimantan.

\section{(1). Pandemik Wilayah Kalteng}
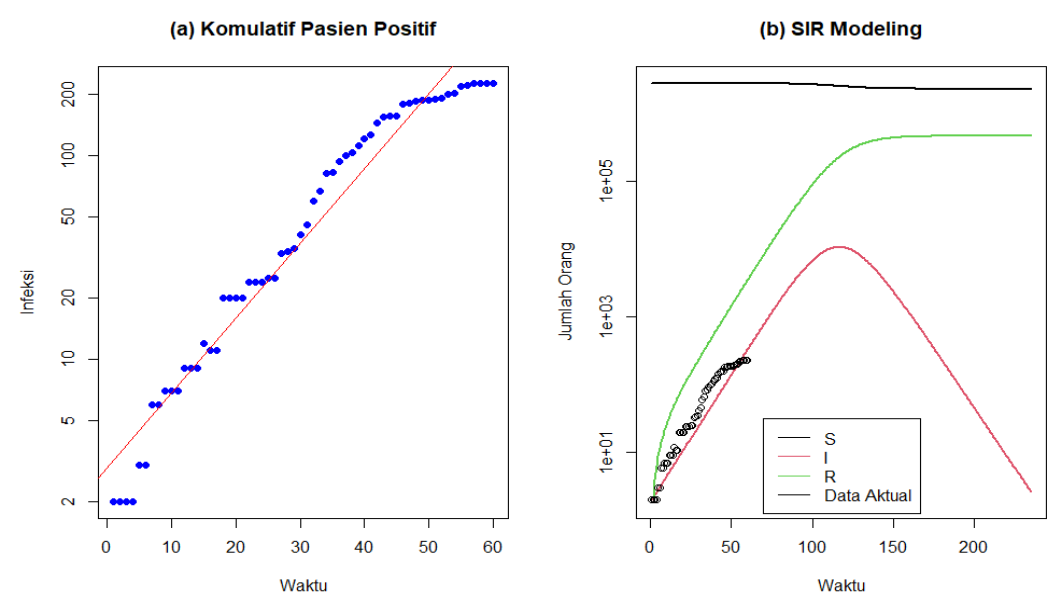

Gambar 2. Simulasi SIR Model dan Data Aktual Wilayah Kalteng 
Untuk daerah Kalteng, data observasi dapat dilihat pada Gambar 2 (a). Pada data aktual untuk pasien positif wilayah kalteng sampai tanggal 18/5/2020 adalah sebanyak 227 orang. Dalam studi ini kami melakukan estimasi pada data aktual dengan mengunakan fit linear regresi model. Pada Gambar 2 (b), SIR model menghasilkan prediksi penyebaran COVID-19 di wilayah Kalteng dengan nilai $\mathrm{R}_{0}=1.09$ yang berarti di wilayah Kalteng terdapat sebanyak 1.09 orang dapat menginfeksi orang lain.

(2) Pandemik Wilayah Kalbar
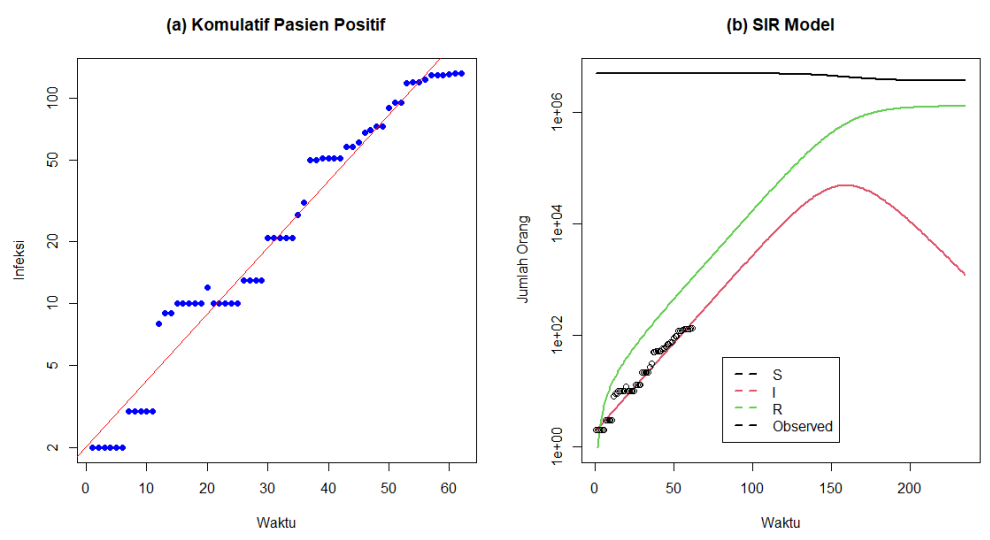

Gambar 3. Simulasi SIR Model dan Data Aktual Wilayah Kalbar

Untuk studi pada wilayah Kalbar dapat dilihat pada Gambar 3 (a). Pada data aktual untuk pasien positif wilayah Kalbar sampai tanggal 18/5/2020 adalah sebanyak 132 orang. Pada Gambar 2 (b) ditampilkan informasi bahwa SIR model menghasilkan prediksi penyebaran COVID-19 di wilayah Kalbar dengan nilai $\mathrm{R}_{0}=1.15$ yang berarti wilayah Kalbar terdapat sebanyak 1.15 orang dapat menginfeksi orang lain.

(3) Pandemik Wilayah Kaltim
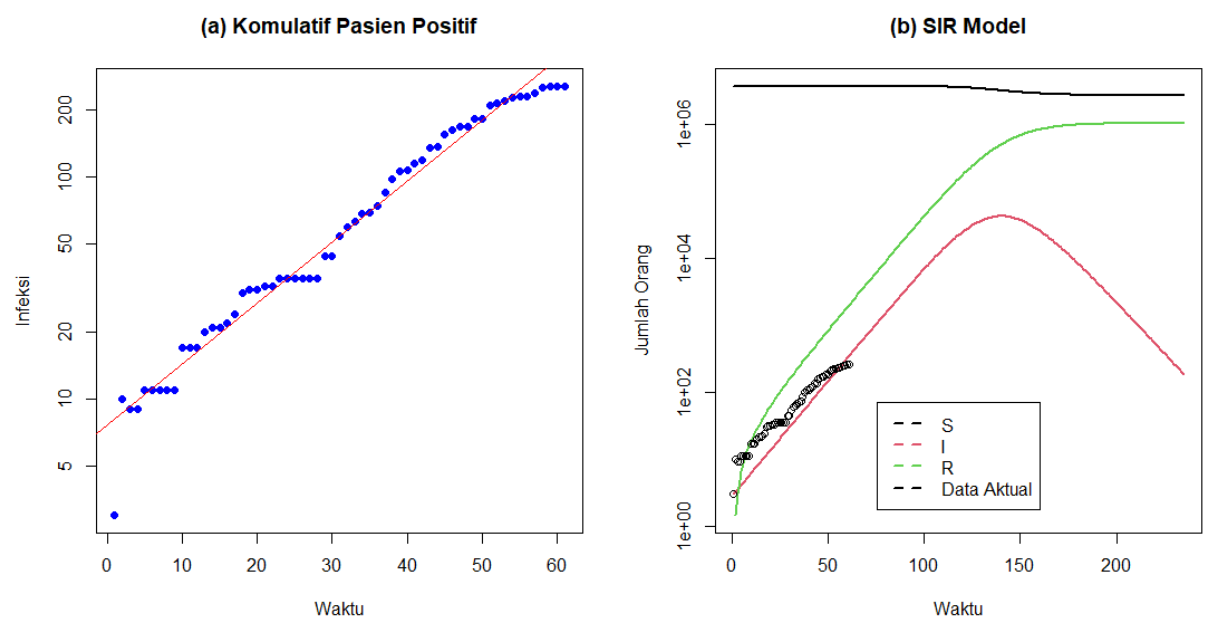

Gambar 4. Simulasi SIR Model dan Data Aktual Wilayah Kaltim 
Untuk studi pada wilayah Kaltim dapat dilihat pada Gambar 4 (a). Pada data aktual untuk pasien positif wilayah Kaltim sampai tanggal 18/5/2020 adalah sebanyak 225 orang. Pada Gambar 2(b), SIR model menghasilkan prediksi penyebaran COVID-19 di wilayah Kaltim dengan nilai $\mathrm{R}_{0}=1.17$ yang berarti wilayah Kaltim terdapat sebanyak 1.17 orang dapat menginfeksi orang lain.

(4) Pandemik Wilayah Kalsel

(a) Komulatif Pasien Positif

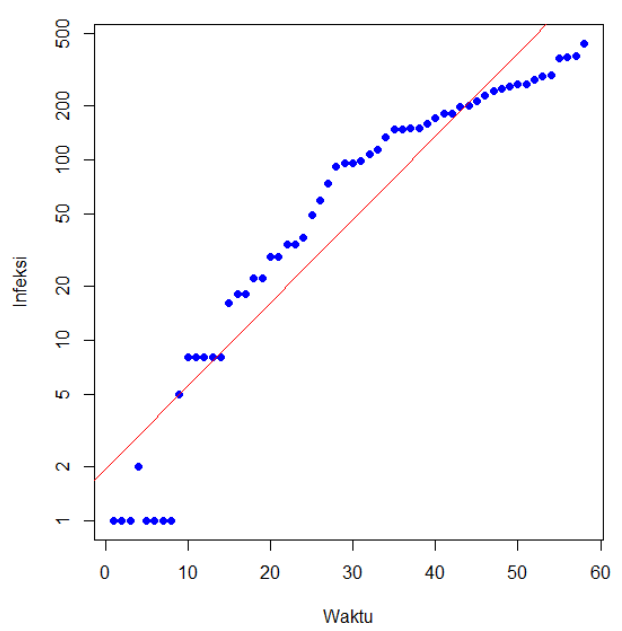

(b) SIR Model

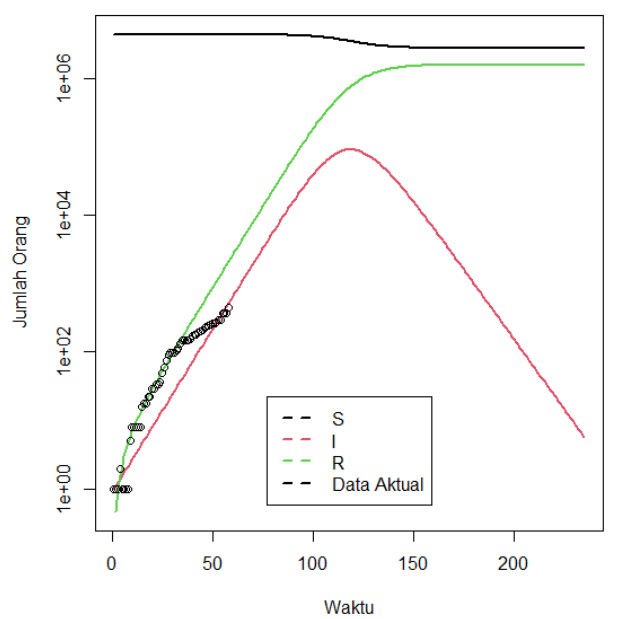

Gambar 5. Simulasi SIR Model dan Data Aktual Wilayah Kalsel

Untuk studi pada wilayah Kalsel dapat dilihat pada Gambar 4 (a). Pada data aktual untuk pasien positif wilayah Kalsel sampai tanggal 18/5/2020 adalah sebanyak 438 orang. Pada Gambar 2 (b) ditampilkan SIR model menghasilkan prediksi penyebaran COVID-19 di wilayah Kalsel dengan nilai $\mathrm{R}_{0}=1.24$ yang berarti wilayah Kalsel terdapat sebanyak 1.24 orang dapat menginfeksi orang lain.

(5) Pandemik Wilayah Kaltara
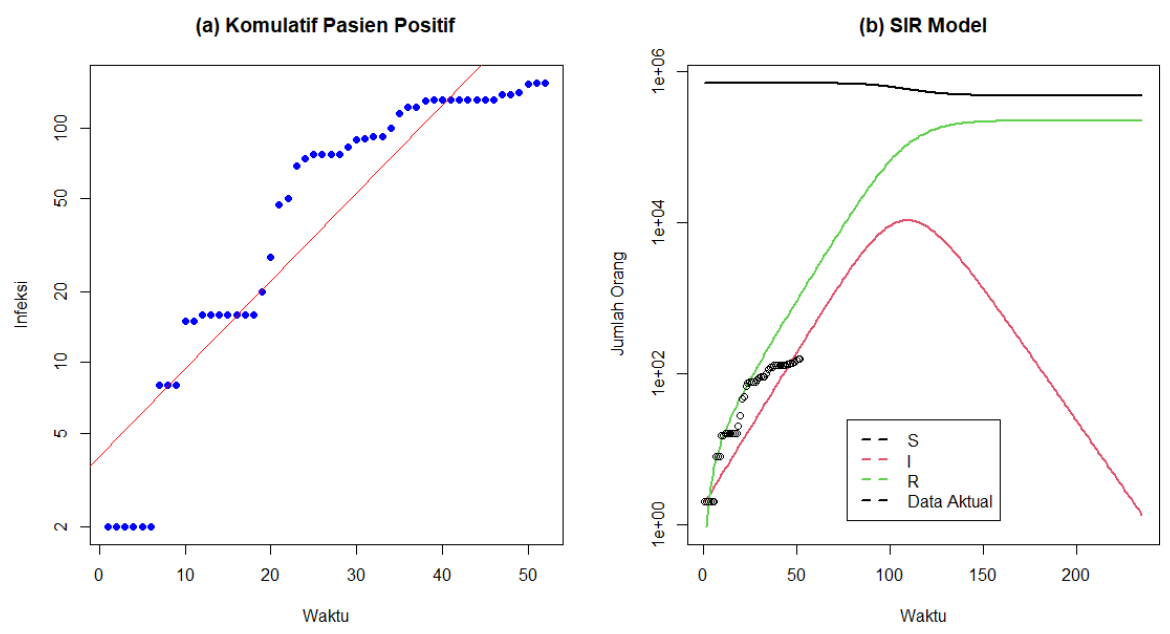
Untuk studi pada wilayah Kaltara dapat dilihat pada Gambar 4 (a). Pada data aktual untuk pasien positif wilayah Kaltara sampai tanggal 18/5/2020 adalah sebanyak 155 orang. Pada Gambar 2(b), SIR model menghasilkan prediksi penyebaran COVID19 di wilayah Kaltara dengan nilai $\mathrm{R}_{0}=1.20$ yang berarti wilayah Kaltara terdapat sebanyak 1.24 orang dapat menginfeksi orang lain.

\subsection{Estimasi Angka Dasar Reproduksi $\mathbf{R}_{0}$}

Dari perhitungan SIR model untuk perwilayah di Kalimantan, dalam studi ini kami melakukan model pencocokan (matching) kurva untuk mengkalkulasi angka dasar reproduksi $\mathrm{R}_{0}$ sebagai referensi nilai dasar rasio reproduksi. Angka Dasar repoduksi adalah nilai rata-rata dari orang yang terinfeksi yang akan menularkan Covid-19 kepada orang lain. Dengan kata lain, jumlah orang yang sehat akan terjangkit oleh orang yang sakit. Dalam Persamaan (4), ketika $\mathrm{R}_{0}>1$ maka penyakit mulai menyebar dalam suatu populasi. Akan tetapi jika $\mathrm{R}_{0}<1$ penyakit tidak menyebar. Namun, semakin besar nilai $\mathrm{R}_{0}$, semakin sulit untuk mengendalikan epidemi dan semakin tinggi kemungkinan pandemi. Kami melakukan perhitungan nilai $\mathrm{R}_{0}$ untuk setiap wilayah di Kalimantan.

Tabel 3. Estimasi Nilai Dasar Reproduksi $\left(\mathrm{R}_{0}\right)$

\begin{tabular}{|c|c|c|c|c|c|c|c|c|c|c|c|c|c|c|}
\hline \multicolumn{3}{|c|}{ Kalbar } & \multicolumn{3}{c|}{ Kaltim } & \multicolumn{3}{c|}{ Kalteng } & \multicolumn{3}{c|}{ Kalsel } & \multicolumn{3}{c|}{ Kaltara } \\
\hline $\mathrm{R}_{0}$ & $\beta$ & $\gamma$ & $\mathrm{R}_{0}$ & $\beta$ & $\gamma$ & $\mathrm{R}_{0}$ & $\beta$ & $\gamma$ & $\mathrm{R}_{0}$ & $\beta$ & $\gamma$ & $\mathrm{R}_{0}$ & $\beta$ & $\gamma$ \\
\hline 1.15 & 0.53 & 0.46 & 1.17 & 0.53 & 0.46 & 1.09 & 1.00 & 0.91 & 1.24 & 0.55 & 0.44 & 1.20 & 0.54 & 0.45 \\
\hline
\end{tabular}

\subsection{Model Herd Immunity}

Untuk model sederhana, proporsi populasi yang perlu diimunisasi secara efektif untuk mencegah penyebaran penyakit yang berkelanjutan, dalam hal ini Fine et al [7] melakukan studi tentang herd immunity. Herd immunity atau kekebalan kelompok adalah kondisi ketika sebagian besar orang dalam suatu kelompok telah memiliki kekebalan terhadap penyakit infeksi tertentu. Semakin banyak orang yang kebal terhadap suatu penyakit, semakin sulit bagi penyakit tersebut untuk menyebar karena tidak banyak orang yang dapat terinfeksi. Proposi individu di dalam sebuah populasi, dimana untuk proteksi agar tidak terjadi oleh infeksi baru.

Tabel 4. Herd Immunity

\begin{tabular}{|c|c|c|c|c|c|}
\hline Wilayah & Kalbar & Kaltim & Kalteng & Kalsel & Kaltara \\
\hline $\mathrm{V}_{\mathrm{c}}$ & $13.6 \%$ & $14.7 \%$ & $8.7 \%$ & $19.8 \%$ & $17.0 \%$ \\
\hline $\mathrm{N}$ & 691.195 & 546.129 & 240.186 & 850.744 & 118.192 \\
\hline
\end{tabular}

\section{Kesimpulan}

Dalam studi ini, pemodelan dengan mengunakan Model SIR pada kawasan regional Kalimantan sangat membantu melihat pola pergerakan sebaran berbasis data aktual. Optimasi pada data aktual di komputasi dengan SIR model menjadi sangat penting untuk mendapatkan prediksi yang akurat. Disamping SIR model, penelitian ini juga mencoba melakukan pemodelan Herd Immunity di kawasan Kalimantan, yang nantinya akan dapat memprediksi jumlah atau kelompok orang yang mampu bertahan terhadap pandemi Covid-19 berdasarkan prediksi dengan SIR model.

\section{Daftar Pustaka}


[1] C. Rothe et al., "Transmission of 2019-NCOV infection from an asymptomatic contact in Germany," $N$. Engl. J. Med., vol. 382, no. 10, pp. 970-971, 2020, doi: 10.1056/NEJMc2001468.

[2] E. Sahafizadeh and S. Sartoli, "Estimating the reproduction number of COVID-19 in Iran using epidemic modeling," medRxiv, p. 2020.03.20.20038422, 2020, doi: 10.1101/2020.03.20.20038422.

[3] K. Liang, "Mathematical model of infection kinetics and its analysis for COVID-19, SARS and MERS," Infect. Genet. Evol., vol. 82, no. April, p. 104306, 2020, doi: 10.1016/j.meegid.2020.104306.

[4] B. P. Singh and G. Singh, "Modeling Tempo of COVID-19 Pandemic in India and Significance of Lockdown," no. March, 2020.

[5] Y.-C. Chen, P.-E. Lu, C.-S. Chang, and T.-H. Liu, "A Time-dependent SIR model for COVID-19 with Undetectable Infected Persons," pp. 1-18, 2020, [Online]. Available: http://arxiv.org/abs/2003.00122.

[6] M. Waqas, M. Farooq, R. Ahmad, and A. Ahmad, "Analysis and Prediction of COVID-19 Pandemic in Pakistan using Time-dependent SIR Model," no. May, 2020, [Online]. Available: http://arxiv.org/abs/2005.02353.

[7] P. Fine, K. Eames, and D. L. Heymann, “'Herd immunity”: A rough guide,” Clin. Infect. Dis., vol. 52, no. 7, pp. 911-916, 2011, doi: 10.1093/cid/cir007. 